\title{
Soil fertility management for organic rice production in the Lao PDR
}

\author{
W. Roder ${ }^{1, \star}$, S. Schürmann ${ }^{2}$, P. Chittanavanh ${ }^{3}$, K. Sipaseuth ${ }^{3}$, and M. Fernandez ${ }^{4}$ \\ ${ }^{1}$ CIP/CFC, PO Box 670, Thimphu, Bhutan. \\ ${ }^{2}$ Swiss College of Agriculture, Zollikofen, Bern, Switzerland. \\ ${ }^{3}$ Project for the Promotion of Organic Farming and Marketing in Lao PDR, Vientiane, Lao PDR. \\ ${ }^{4}$ Project Promotion of Organic Rice from Lao PDR, Vientiane, Lao PDR. \\ *Corresponding author: wrjakar@druknet.bt
}

\begin{abstract}
Rice is the most important agricultural commodity of the Lao People's Democratic Republic (Lao PDR), produced largely using traditional methods with limited inputs of fertilizers and other chemicals. The country has a wide diversity in rice production systems and rice varieties, with over 3000 different varieties recorded. The rich diversity and the production environment and methods are favorable for organic rice production. Investigations were carried out to describe soil fertility conditions, management practices, opportunities and problems associated with organic production methods for rice. Soils used for rice production are mostly of low fertility, with low organic matter and N-availability. In spite of this, virtually no fertilizer inputs are used for upland rice production. Inorganic fertilizer inputs for lowland rice production have increased rapidly over the past decade, but are still below $20 \mathrm{~kg} \mathrm{ha}^{-1}$. The most important nutrient sources are rice straw and manure from buffalo and cattle. Chromolaena odorata plays an important role in nutrient cycling in upland rice systems and is sometimes added to lowland fields. In a range of fertility management studies, yield increase ranged from 2 to $89 \%$ for manure, straw or rice husk applied at modest rates $\left(3 \mathrm{tha}^{-1}\right), 32-156 \%$ for modest rates of inorganic fertilizer $\left(60 \mathrm{~kg} \mathrm{~N} \mathrm{ha}^{-1}\right)$ and $36-167 \%$ for combined application of manure or crop residues with inorganic fertilizer. The response to locally produced commercial organic fertilizer was poor. The most promising inputs and strategies available to optimize yields in organic rice production systems are (1) optimizing use of locally available nutrients, mostly from manure, crop residues and weed biomass, (2) $\mathrm{N}$ addition through green manure and legumes growing in rotation and (3) additions of $\mathrm{P}$ through guano or rock-phosphate. The Lao PDR is fortunate to have substantial bat guano deposits in limestone caves. Extensive experience is available on straw and husk management for lowland systems and green manure species for upland production systems.
\end{abstract}

Key words: manure, rice straw, rice husks, organic fertilizer, rock-phosphate, guano, green manure species

\section{Introduction}

Rice is by far the most important crop for the Lao People's Democratic Republic (Lao PDR), grown on more than 700,000 ha annually. Based on water management, the ricegrowing areas are grouped into rainfed lowland, irrigated lowland and upland rice; each of these represents approximately 75,10 and $15 \%$ of the total area under rice ${ }^{1}$. Rice yields are generally low with a national average of 3.4 , 4.5 and $1.8 \mathrm{tha}^{-1}$ for rainfed lowland, irrigated lowland and upland, respectively ${ }^{1}$. Most of the rice varieties are glutinous. Lao rice producers generally consider the absence of a market or the low market price as the main factors limiting production (Helvetas, 2005. ProRicePhase I, 2006-2008. Project Document, Vientiane, unpublished). At the same time, the production of speciality rice and/or organic rice for export markets is often seen as a potentially promising opportunity ${ }^{2}$. Within the past few years, the interest for organic production and expectations from market opportunities for organic products from the Lao PDR have increased rapidly ${ }^{3}$. The Ministry of Agriculture and Forestry and various projects and organizations are promoting organic production methods for market production and for home consumption. Prevailing conditions favoring organic rice production generally recognized include: (1) many rainfed rice production environments are marginal with limited response to high yielding varieties and high input systems; (2) Lao rice producers presently use only limited fertilizer inputs; and (3) traditional production methods still widely used are largely organic (Helvetas, 2005. ProRice-Phase I, 2006-2008. Project Document, Vientiane, unpublished). 
In the European or North American context, organic agriculture with annual crops is mostly based on mixed farming systems with legumes in the rotation and high inputs of manure. Under European conditions, cereal grain yields from organic production systems are about 10-30\% lower when compared to conventional systems. Furthermore, studies comparing organic and conventional production have generally used the same rates of $\mathrm{N}$ provided either through manure or compost for organic treatments or through inorganic fertilizers with or without manure for conventional treatments ${ }^{4,5}$. With $\mathrm{N}$ application rates of $100 \mathrm{~kg}$ and above, manure applications for organic treatments are in the range of $10-20 \mathrm{tha}^{-1}$.

Soil fertility management will be a major challenge for organic rice production in the Lao PDR. The European and North American experiences will have only limited application as the Lao rice farmers will not have the benefits of a mixed farming system nor will they have access to the required quantities of manure. Substantial information on soil fertility management, the use of organic fertilizers, residue management and green manure has been generated under Lao conditions; some of these results and experiences can be directly applied for organic production. Investigations were carried out with the objectives to:

1. describe current soil fertility conditions and management practices for the major Lao rice production systems,

2. summarize experimental soil fertility management data relevant for organic rice production in Laos, and

3. describe inputs available and recommendations given for soil fertility management in organic production systems.

\section{Methods}

\section{Locally available source of inputs}

Information on existing and potential locally available sources for soil fertility management in organic agriculture was collected from the literature and contacts with input suppliers and fertilizer factories.

\section{Literature review and secondary data}

Documents and information relating to fertility management in general and the use of organic inputs in particular were collected from published and unpublished sources.

\section{Survey of rice producers}

An economic survey was carried out in 2004, in three districts of Champasak province in collaboration with the Provincial Agriculture Service. Formal survey questionnaires were used to collect production and economic data. For the present paper, only the cost of inputs and rice yields were used.

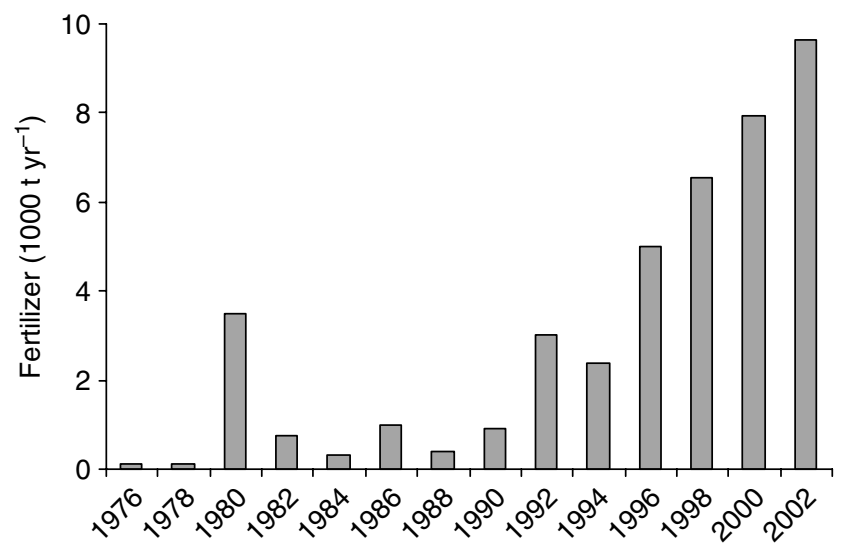

Figure 1. Fertilizer import (each bar represents the average of the year indicated and the year before ${ }^{17}$ ).

\section{Studies by Lao-IRRI project and others}

From 1990-2002, the Lao-International Rice Research Institute (IRRI) project carried out a range of studies evaluating the effect of organic fertilizer, manure, rockphosphate, straw applications and green manure in lowland and upland rice production systems across a range of environments $^{6-14}$. The results available in annual reports were revisited and summarized.

\section{Survey organizations recommending organic agriculture}

Information was collected from non-government organizations which recommend organic agriculture or "clean agriculture' through informal interviews supported by questionnaires.

\section{Results}

\section{Soil fertility and current management practices for lowland rice}

Lowland rice soils in the southern part of Laos are predominantly Acrisols ${ }^{15}$. Typically, these soils are highly weathered, have a low inherent fertility, a low $\mathrm{pH}$ and a low cation-exchange capacity. Soil data $(0-20 \mathrm{~cm})$ indicate that $80 \%$ of the soils in the south contain less than $2 \%$ organic matter, $68 \%$ are coarse textured sand and $87 \%$ have a $\mathrm{pH}$ of less than 5.5. Of all the elements tested, $\mathrm{N}$ was the most important yield-limiting factor but the severity varied considerably between sites ${ }^{15}$. The second most limiting factor was P, with $71 \%$ of the sites in the south and $37 \%$ of the sites in the north responding to $\mathrm{P}$ application. In spite of the low fertility, using chemical fertilizer for rainfed lowland rice production is a recently introduced practice for Laos. In a survey conducted in 1996, 60\% of the farmers reported that they started using fertilizer only after $1995^{16}$. In the past ten years, fertilizer consumption has increased rapidly (Fig. 1), but based on the FAO statistics ${ }^{17}$ the average fertilizer consumption is still $<10 \mathrm{~kg} \mathrm{ha}^{-1}$ land 


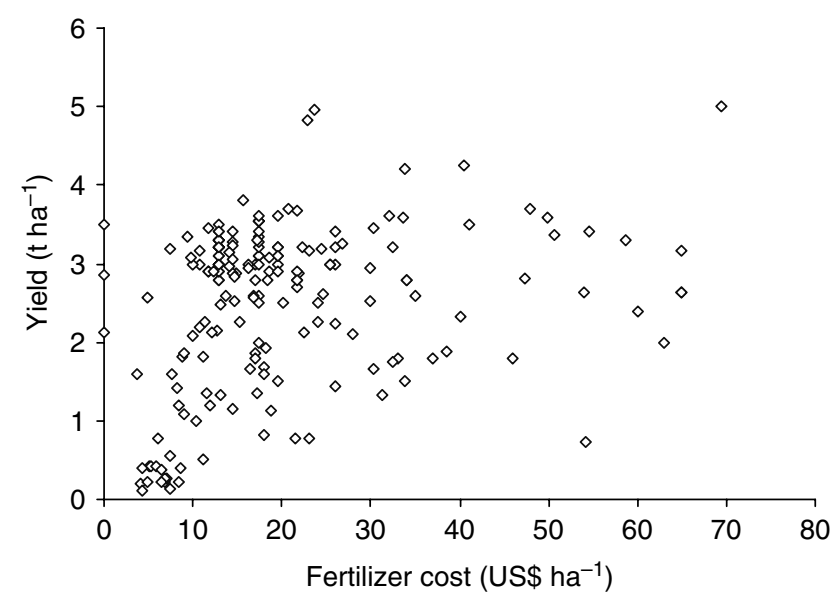

Figure 2. Investment in fertilizer and rice yield for rainfed rice in Kong, Sukumma and Phonethong districts (Champasak province).

cultivated. In the survey in Champasak province, only three out of 196 households surveyed used no fertilizer for rainfed rice production. There was a strong relationship between investment in fertilizer and rice yield (Fig. 2), but the data also show that there was little return for investments in fertilizer above US\$20 ha ${ }^{-1}$.

\section{Soil fertility and current management practices in upland rice}

Upland soils are generally poor, mainly red-yellow, podzolic and reddish brown lateritic, leached and acidic, with low water-holding capacity ${ }^{18}$. Soil fertility is generally cited as a major constraint in upland rice production. Yet, extensive investigations focusing on soil-related factors that may affect rice yield failed to show a conclusive relationship between conventional soil fertility parameters and rice yield, and fertilizer applications did not show consistent results $^{18}$ (Table 1). In spite of the inconsistent response, $\mathrm{N}$ clearly limits rice yields. $\mathrm{N}$-stress is especially likely to affect yield during the later part of the growing season as indicated by a strong relationship between leaf chlorophyll at the time of flowering and yield ${ }^{18}$. Application of $\mathrm{P}$ resulted in increased $\mathrm{P}$ uptake of $38 \%$ but had no consistent effect on grain yield ${ }^{19}$. Upland rice producers presently do not apply any fertilizer or manure. With a gradual decline in the level of organic matter because of shorter fallow cycles, it is expected that $\mathrm{N}$ stress may become more pronounced. For sustained upland rice production, it will be important to limit $\mathrm{N}$ and organic matter losses and to provide sufficient $\mathrm{N}$ during the critical stages of the rice crop through $\mathrm{N}$-rich residues of forages/crops grown in rotation and/or appropriate fertilizers.

Various studies focused on the effect of residue management on rice yield, weed biomass and other parameters ${ }^{18,20,21}$. Although drought is considered a major yield constraint, no positive short-term benefits of mulching on grain yield could be demonstrated except in a study involving mulching with pigeonpea (Cajanus cajan)
Table 1. Results of fertilizer studies in upland rice ${ }^{20}$.

\begin{tabular}{lc}
\hline Parameters studied & $\begin{array}{c}\text { Increase in } \\
\text { rice yield (\%) }\end{array}$ \\
\hline Application of N during early phase & $0-20$ \\
Application of N during booting stage & $0-40$ \\
Application of N after flowering & $0-70$ \\
Application of N in two splits & $0-69$ \\
Application of N in three splits & $0-80$ \\
Application of P fertilizer & $0-15$
\end{tabular}

Table 2. Effect of residue management and mulching in upland rice ${ }^{20}$.

\begin{tabular}{ll}
\hline Parameters studied & $\begin{array}{c}\text { Effect on rice } \\
\text { yield (\%) }\end{array}$ \\
\hline $\begin{array}{l}\text { Mulching with rice straw } \\
\text { Mulching with pigeon pea residue }\end{array}$ & Reduction 0-50 \\
$\begin{array}{l}\text { Mulching with Chromolaena } \\
\text { odorata (fresh) }\end{array}$ & 0 \\
\hline
\end{tabular}

residues $^{22}$ (Table 2). Burning of crop and fallow vegetation residues consistently reduced weed biomass and made field preparation easier ${ }^{21}$.

\section{Nutrient sources for organic production}

Lao rice producers mostly rely on the production capacity of their soils. Until recently, limited quantities of nutrients were added through manure or inorganic fertilizers and, before 1980, the quantities of chemical fertilizers imported were negligible ${ }^{17}$. Rice producers generally do not optimize the benefits from manure and crop residues. Straw removed at harvest is often burned after threshing or used as livestock feed and only limited efforts are made to increase the quantity or quality of manure produced.

The most important nutrient sources for organic rice production will be manure, crop residues and compost made from materials available at village level. Although most of these nutrients are already used, there are opportunities to improve the utilization and reduce losses, especially for N. The weed Chromolaena odorata plays a special role in nutrient cycling, especially in upland environments $^{23}$. Occasionally, biomass of this species is also used by lowland rice producers.

Cattle and buffalo are important sources of plant nutrients and agents in accelerating nutrient cycling. To some extent, they also serve as a vehicle for transferring nutrients from fallow land and forest to the rice fields. The available statistics indicate that there are 1.8 head cattle and 1.6 buffalo per hectare of rice. Lowland rice farmers are more likely to have buffalo, while upland rice farmers are more likely to have cattle. Traditionally, buffalo are used for field preparation in lowland systems. Lowland rice farmers are, however, gradually replacing buffalo with tractors ('Tractors versus buffaloes', Vientiane 


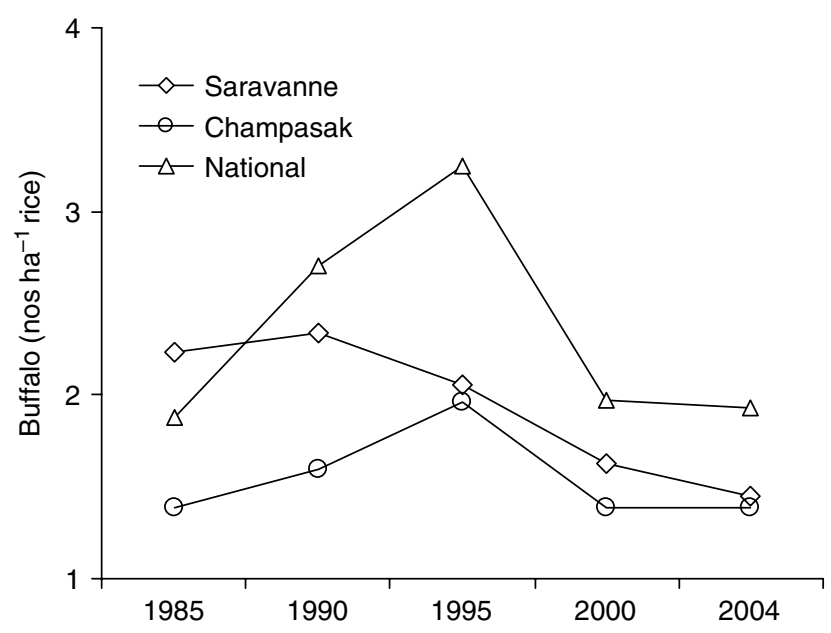

Figure 3. Buffalo density (numbers per hectare of lowland rice) given for the national level and two major rice-producing provinces Saravanne and Champasak ${ }^{1}$.

Times, July 12, 2005) and there is a tendency of decreasing livestock numbers (Fig. 3). Adding micro-organisms to hasten decomposition of organic matter is widely recommended for compost making, especially a technology known as EM (effective micro-organism). This technology may accelerate nutrient cycling and availability but it does not bring additional nutrients to a system.

Commercially available sources of nutrients that are permitted for organic agriculture are biofertilizers, bat guano and rock-phosphate. In the late 1990s, the government of Lao PDR established ten biofertilizer factories ${ }^{24}$, with a production potential of $88,400 \mathrm{tyr}^{-1}$. In the year 2004, these factories produced about 20,000 $\mathrm{t}$. All factories use similar raw material, with peat from a lake being the main ingredient $(60-80 \%)$. A range of other products such as slaughterhouse by-products, by-products from beer, sugar and tobacco processing, rock-phosphate and guano are added and composted together with the peat (Manager, Dong Xiengdy factory, Vientiane, personal communication, 2005). All components are mixed, a solution of microorganisms is sprayed on and then the mixture is fermented for 20-30 days. Analytical data are available for five factories (Table 3). Because of limited crop response, farmers have shown little interest and five factories stopped production in 2005 due to limited markets. Furthermore, according to the International Federation of Organic Agriculture Movements (IFOAM) standards, fertilizers with peat as a base would be allowed for potted plants only ${ }^{25}$.

Laos is very fortunate to have extensive deposits of bat guano in limestone caves (W. Roder, P. Chittanavanh, K. Sipaseuth, and M. Fernandez, 2005. Inputs available for organic farming, PROFIL/DoA/Helvetas, Vientiane, unpublished). It is quite likely that the deposits referred to as 'rock-phosphate' in some documents are actually also mineralized guano. The $\mathrm{P}$ and $\mathrm{N}$ contents of the guano deposits vary (Table 4). The mineral content is largely
Table 3. Nitrogen and phosphorus composition of biofertilizers ${ }^{24}$.

\begin{tabular}{llc}
\hline & \multicolumn{2}{c}{ Content (\%) } \\
\cline { 2 - 3 } Factories & $\mathbf{N}$ & $\mathbf{P}_{\mathbf{2}} \mathbf{O}_{\mathbf{5}}$ \\
\hline Dong Xiengdy & 1.5 & 2 \\
Xiengda & 2.8 & 8.3 \\
Maliny & 1.5 & 5 \\
Savannakhet & 3 & 5 \\
Champasack-46 & 1.5 & 1.5 \\
\hline
\end{tabular}

Table 4. Nitrogen and phosphorus content of five guano samples originating from Khammuone Province.

\begin{tabular}{lcc}
\hline & \multicolumn{2}{c}{ Content (\%) } \\
\cline { 2 - 3 } Nutrient & Average & Range \\
\hline Nitrogen & 0.12 & $0.02-0.35$ \\
Phosphorus & 3.6 & $0.7-5.7$ \\
\hline
\end{tabular}

dependent on the age and the stage of mineralization. The milled guano is presently sold for about US\$70 $t^{-1}$. At this price, it is a cheaper source of $\mathrm{P}$ than single or triple superphosphate. Although guano is accepted as an input for organic production, it is important to emphasize that guano is a non-renewable resource, as rapid exploitation will lead to its depletion.

\section{Experiences with inputs permitted in organic agriculture}

Effects of manure and crop residues for lowland rice. The Lao-IRRI project has evaluated effects of manure, straw or rice husk over a wide range of environments $^{8-14}$ (Table 5). These studies showed that manure, straw or rice husk applied at modest rates can increase yields by $10-80 \%$, while modest rates of inorganic fertilizer applied alone can increase yields by $30-150 \%$. In all experiments, the yield increase was consistently higher with inorganic fertilizers and highest when inorganic fertilizer was combined with manure application. The residual effect of repeated manure applications was not apparent. In these studies, the nutrient quantities applied through manure or crop residues were, however, always below the nutrient quantities applied through inorganic fertilizers.

Current soil fertility management recommendations of the government extension system emphasize the benefits of using straw and rice husk. Rice farmers are, however, often reluctant to follow these recommendations. Farmers' limited interest in utilizing straw and manure are influenced by the difficulties in collecting and transporting manure or straw and in field preparation when using straw. Furthermore, crop yellowing is often observed during the first week following transplanting when straw is incorporated, due to $\mathrm{N}$ immobilization. 
Table 5. Effect of $\mathrm{N}$ fertilizer, manure, rice straw and rice husk on rice yields.

\begin{tabular}{|c|c|c|c|c|c|c|c|c|c|c|c|}
\hline \multirow[b]{2}{*}{ Year/season } & \multicolumn{4}{|c|}{ Fertilizer $\left(\right.$ tha $\left.^{-1}\right)$} & \multirow[b]{2}{*}{ Yield $\left(\mathrm{tha}^{-1}\right)$} & \multicolumn{5}{|c|}{ Yield increase $(\%)$} & \multirow[b]{2}{*}{ Reference } \\
\hline & $\mathbf{N}$ & $\mathbf{M}$ & $\mathbf{S}$ & $\mathbf{H}$ & & $\mathbf{N}$ & M & $\mathbf{S}$ & $\mathbf{H}$ & $\mathbf{N}+\mathbf{M}$ & \\
\hline \multicolumn{12}{|c|}{ Repeated over years on same plot (residual effects for 2 nd and 3 rd year) } \\
\hline \multicolumn{12}{|c|}{ Saravane district (Saravane) and Phonethong district (Champasack) } \\
\hline 1st year & 0.06 & 2 & 2 & 2 & 1.35 & 121 & 48 & 48 & 50 & 182 & 9 \\
\hline 2nd year & 0.06 & 2 & 2 & 2 & 1.21 & 156 & 69 & 68 & 69 & 192 & 10 \\
\hline 3rd year & 0.06 & 2 & 2 & 2 & 1.92 & 67 & 61 & 66 & 60 & 103 & 11 \\
\hline 4 th year ${ }^{1}$ & 0.06 & 2 & 2 & 2 & 1.57 & 98 & 89 & 75 & 59 & 167 & 12 \\
\hline \multicolumn{12}{|c|}{ Xiengkho district (Houaphanh), Vapi district (Saravane) and Peng district (Xayabouli) } \\
\hline 1st season & 0.06 & 2 & - & - & 1.90 & 84 & 8 & - & - & 98 & 12 \\
\hline 2nd season & 0.06 & 4 & - & - & 2.63 & 44 & 19 & - & - & 58 & 13 \\
\hline \multicolumn{12}{|c|}{ New sites (no residual effects) } \\
\hline & 0.06 & 5.2 & - & 1.3 & 2.41 & 41 & 25 & - & 15 & 67 & 8 \\
\hline & 0.06 & 2 & - & 2 & 2.70 & 32 & 18 & - & 19 & 48 & 10 \\
\hline & 0.06 & 2 & - & - & 3.24 & 32 & 2 & - & - & 36 & 11 \\
\hline
\end{tabular}

$\mathrm{N}=$ inorganic $\mathrm{N}$ fertilizer $(\mathrm{t} \mathrm{N}) ; \mathrm{M}=$ manure; $\mathrm{S}=$ rice straw; $\mathrm{H}=$ rice husk $\left(\mathrm{M}, \mathrm{S}\right.$ and $\mathrm{H}$ quantities in $\mathrm{tha}^{-1}$ based on dry weight).

${ }^{l}$ Phonethong district only.

Table 6. Effect of commercial organic fertilizers on rice yields.

\begin{tabular}{|c|c|c|c|c|c|c|c|}
\hline \multirow{2}{*}{$\begin{array}{l}\text { Locations } \\
\text { (numbers) }\end{array}$} & \multirow[b]{2}{*}{ Seasons } & \multicolumn{2}{|c|}{ Fertilizer $\left(\right.$ t ha $\left.^{-1}\right)$} & \multirow{2}{*}{$\begin{array}{c}\text { Yield } \\
\left(\mathrm{tha}^{-1}\right)\end{array}$} & \multicolumn{2}{|c|}{ Yield increase (\%) } & \multirow[b]{2}{*}{ Reference } \\
\hline & & $\mathbf{N}$ & COF & & $\mathbf{N}$ & COF & \\
\hline 2 & 2 & 0.06 & 1.0 & 2.0 & 52 & 18 & 9,10 \\
\hline 5 & $3-4$ & 0.06 & 1.0 & 2.0 & 66 & 20 & 14 \\
\hline 12 & 1 & 0.07 & 2.0 & 2.79 & 50 & 12 & 13 \\
\hline
\end{tabular}

$\mathrm{N}=$ inorganic $\mathrm{N}$ fertilizer in $(\mathrm{t} \mathrm{N})$.

$\mathrm{COF}=$ commercial organic fertilizer in $\mathrm{t}$ of fertilizer $(1.5-3 \% \mathrm{~N})$.

Commercially available organic fertilizers and rockphosphate. Data are available from studies with commercially available biofertilizer across a wide range of locations (Table 6). One of these studies was repeated over four rice crops. The response to the biofertilizer is generally poor. A recent FAO project for the promotion of organic fertilizers tested the biofertilizer across a wide range of rice production environments with application rates of $600 \mathrm{~kg} \mathrm{ha}^{-1}$ but no yield response was observed ${ }^{24}$. This study concluded that the low nutrient content of the biofertilizers required high application rates, making the fertilizer too expensive.

The results of the limited studies with rock-phosphate (imported from Kunming, People's Republic of China) are very promising (Table 7). The response to rock-phosphate was generally better than to triple superphosphate. Unfortunately, the locally available guano was not included in these studies.

\section{Experiences with green manure species}

Green manure species have been widely tested and recommended for all rice-growing environments ${ }^{7,18}$. In spite of this, none of the species/systems recommended have been adopted on a wider scale. Both lowland and upland rice farmers sometimes use grain legumes in rotation with rice, especially Vigna species and peanuts.

Lowland rice environments. Green manure species tested included Aeschynomene afraspera, Crotalaria juncea, Sesbania aculeate, S. rostrata, Vigna radiata and $V$. unguiculata ${ }^{7}$. Based on studies repeated over locations and years, it was found that $C$. juncea and $V$. radiata are unsuitable for periodically saturated soil conditions that are a normal feature in rainfed lowland environments. $S$. rostrata was promising but it could not be recommended because it is a host of the root-knot nematode (Meloidogyne graminicola). In order to have optimum $\mathrm{N}$-fixation, green manure legumes generally require higher $\mathrm{P}$ levels than rice. In a study across three locations, the dry matter production of $S$. rostrata was $0.6,2.4$ and $2.9 \mathrm{tha}^{-1}$ with 0,30 and $60 \mathrm{~kg} \mathrm{Pha}^{-1}$, respectively ${ }^{6}$. Phosphorus is likely to be a major limitation for using green manure in some lowland rice-growing environments.

Upland rice environments. A wide range of legumes have been tested for fallow and/or soil fertility management in upland rice production systems. Already in 1930, 
Table 7. Effect of rock-phosphate on rice yields.

\begin{tabular}{|c|c|c|c|c|c|}
\hline \multirow[b]{2}{*}{ Location $^{I}$} & \multirow{2}{*}{$\begin{array}{c}\text { Years after } \\
\text { 1st application }\end{array}$} & \multirow[b]{2}{*}{ Yield (t ha $\left.{ }^{-1}\right)$} & \multicolumn{2}{|c|}{ Yield increase $(\%)$} & \multirow[b]{2}{*}{ Reference } \\
\hline & & & $\mathbf{T S P}^{2}$ & $\operatorname{Rock} \mathbf{P}^{3}$ & \\
\hline Vientiane & 0 & 3.23 & 6 & 14 & 8 \\
\hline Vientiane & 1 & 3.5 & 8 & 24 & 9 \\
\hline Vientiane & 2 & 2 & 10 & 10 & 10 \\
\hline Houaphanh & 0 & 4.33 & 14 & 3 & 9 \\
\hline Houaphanh & 1 & 3.2 & 28 & 25 & 10 \\
\hline Houaphanh & 2 & 3.3 & 16 & 35 & 11 \\
\hline
\end{tabular}

1 Fertilizer application was repeated yearly for Vientiane. For Houaphanh, the fertilizer was applied in the first year only.

2 Triple superphosphate applied at the rate of $60 \mathrm{~kg} \mathrm{P}_{2} \mathrm{O}_{5} \mathrm{ha}^{-1}$.

${ }_{3}$ Rock-phosphate, applied at the rate of $320 \mathrm{~kg} \mathrm{P} \mathrm{P}_{5}$.

Goubeaux $^{26}$ worked with 46 legume species. The presence of Mimosa invisa, a serious weed in some isolated upland areas, is an unpleasant testimony of those activities. The main species promoted by various agencies for fallow improvement over the past two decades were Leucaena leucocephala, Gliricidia sepium, pigeon pea and Calliandra calothyrsus. In addition, the following species were recommended based on work carried out by the Lao-IRRI project: Arachis pintoi, Calopogonium caeruleum, Centrosema pubescens, Crotalaria anagyroides, Lablab purpureus, Leucaena diversifolia, Stylosanthes guianensis, Pueraria phaseoloides and Mucuna cochinchinensis ${ }^{18}$. Most of the species evaluated have multiple uses, including food, fodder and/or fuel. Pigeonpea received special attention, with activities focusing on: collection and testing of local and introduced cultivars, establishment methods, rotation effects, residue management and weed suppression ${ }^{22}$. Important findings from studies carried out between 1991 and 1999 over a range of locations include:

- replacing fallow vegetation with legumes had generally no effect on rice yield and weed biomass ${ }^{18}$;

- interplanting rice with shrubby perennial legumes (pigeon pea, L. leucocephala and C. anagyroides) can add to total biomass produced and suppress weeds during the dry season fallow ${ }^{20}$;

- A. pintoi is not suitable for live mulch systems due to competition for moisture ${ }^{27}$;

- pigeon pea, $C$. anagyroides and S. guianensis are the most promising legume species for upland rice systems ${ }^{18}$;

- residue management is a critical issue, and for most species tested, field preparation without burning was difficult ${ }^{28}$

- intercropping with L. leucocephala reduced rice yield in dry years ${ }^{20}$; and

- most legume species can be easily established by broad-casting seed immediately after the last rice weeding or by mixing seed with rice seed and dibbling together. The latter can, however, affect rice yield negatively ${ }^{29}$.
Table 8. Technologies recommended for soil fertility management.

\begin{tabular}{lcc}
\hline & \multicolumn{2}{c}{ Number of agencies ${ }^{\boldsymbol{I}}(\boldsymbol{n}=\mathbf{1 1})$} \\
\cline { 2 - 3 } $\begin{array}{l}\text { Technology } \\
\text { recommended }\end{array}$ & $\begin{array}{c}\text { Recommending } \\
\text { technology }\end{array}$ & $\begin{array}{c}\text { Documented } \\
\text { results }\end{array}$ \\
\hline $\begin{array}{c}\text { Stop using inorganic } \\
\text { chemicals }\end{array}$ & 10 & 0 \\
$\begin{array}{l}\text { Use compost } \\
\text { EM for composting and } \\
\text { pest management } \\
\text { Bio-extracts for pest } \\
\text { management }\end{array}$ & 8 & 0 \\
\hline
\end{tabular}

1 Agencies recommending technology.

EM, effective micro-organisms.

\section{Recommendations given for soil fertility management}

Of all the organizations/projects visited, only two promote 'organic production methods' as per international definitions $^{25}$. All other projects/organizations promote 'chemical free agriculture'. The main recommendation given to the producer is 'stop using chemicals' (Table 8). Some organizations have no recommendation for soil fertility and pest management. Others recommend the use of compost. Bio-extract, effective micro-organisms and biocontrol are the only other recommendations given. Surprisingly, none of the organizations promotes the use of green manure.

Except for effective micro-organisms, no information was found documenting systematic evaluation of the recommendations under Lao conditions. Similarly, no reliable information is available on the adoption rate for any of the recommended technologies. The limited availability of plant nutrients or sources of organic fertilizers (especially manure) was, however, recognized by two organizations as the main problem. 


\section{Implications for organic rice production}

Lao farmers produce rice under marginal conditions with low yields and low yield potentials. This is often considered as an advantage for organic production as response to inorganic fertilizers is limited. Yet, soil fertility will be the most important constraint for organic rice production. In order for rice producers to benefit from organic production, practical, effective and economic soil management strategies have to be available. Strategies and recommendations need to be based on local soil conditions, existing management practices and locally available nutrient sources. Unlike in Europe or Northern America, the farmers have to develop soil fertility management strategies without having the benefits of a traditional mixed cropping system with legumes or a system with large volumes of organic manure available. Depending on the evolving production system, it may be necessary to import certain inputs, especially phosphate.

The most promising technologies available to optimize yields in organic systems include:

- optimize the use of locally available nutrients, mostly from manure, crop residues and weed biomass,

- add $\mathrm{N}$ to the system through green manure and legumes growing in rotation, and

- add P through guano or rock-phosphate.

Through optimal management of these nutrient sources, it will be possible to maintain or even improve present rice yields in most situations. Producers may require support in the supply of inputs (seed of green manure species, guano and rock-phosphate), marketing of new products (pulses grown in rotation and livestock products) and the development of appropriate management strategies.

Research, advisory services and other agencies making recommendations for soil fertility management in organic production systems need to be keenly aware that:

- Constant efforts have to be made to minimize confusion about the meaning of 'organic agriculture'. Until recently, most agriculture in Lao PDR was organic, yet the idea of organic agriculture is introduced as a 'new concept' with a wide range of interpretations. This has resulted in much confusion and misunderstandings.

- The principles of soil fertility management are the same for organic and conventional systems. Plants do remove nutrients from the soil, which have to be replaced.

- When developing/recommending soil fertility management strategies, it will be important to always be cautious about additional labor or investments.

Acknowledgements. Writing this manuscript was made possible through the support of the Department of Agriculture, Lao PDR and the Swiss Association for International Cooperation (Helvetas).

\section{References}

1 National Statistical Center. 2005. Statistics Lao PDR 19752005. Committee for Planning and Investment, National Statistics Centre, Vientiane.
2 Schiller, J.M., Rao, S.A., Hatsadong, P.H., and Inthapanya, P. 2001. Glutinous rice varieties of Laos, their improvement, cultivation, processing and consumption. In R.C. Chaudhary and D.V. Tran (eds). Specialty Rices of the World: Breeding, Production and Marketing. Science Publishers, Enfield, NH. p. 19-34.

3 Chittanavanh, P., Sommani, P., Sanaphanh, K., and Roder, W. 2005. Opportunities for organic products in Vientianeperceptions of consumers and traders Consumer and trader awareness and interest. In Proceedings of the IFOAM Organic World Congress, Adelaide, South Australia.

4 Raupp, J. 2001. Zwanzig Jahre Langzeit-Düngungsversuch. Oekologie \& Landbau 118(2):29-31.

5 Mäder, P., Fliebach, A., Dubois, D., Gunst, L., Fried, P., and Niggli, U. 2002. Soil fertility and biodiversity in organic farming. Science 96:1694-1696.

6 Lao-IRRI. 1996. Annual report. Lao-IRRI, Vientiane.

7 Lao-IRRI. 1997. Annual report. Lao-IRRI, Vientiane.

8 Lao-IRRI. 1998. Annual report. Lao-IRRI, Vientiane.

9 Lao-IRRI. 1999. Annual report. Lao-IRRI, Vientiane.

10 Lao-IRRI. 2000. Annual report. Lao-IRRI, Vientiane.

11 Lao-IRRI. 2001. Annual report. Lao-IRRI, Vientiane.

12 Lao-IRRI. 2002. Annual report. Lao-IRRI, Vientiane.

13 Lao-IRRI. 2003. Annual report. Lao-IRRI, Vientiane.

14 Lao-IRRI. 2004. Annual report. Lao-IRRI, Vientiane.

15 Linquist, B. and Sengxua, P. 2001. Nutrient management of rainfed lowland rice in the Lao PDR. International Rice Research Institute, Los Banos, the Philippines.

16 Pandey, S. and Sanamongkhoun, M. 1998. Rainfed lowland rice in Laos: a socio-economic bench-mark study. International Rice Research Institute, Los Banos.

17 FAO. 2005. FAOSTAT on-line statistical service. FAO, Rome, Italy. Available at Web site: http://apps.fao.org (verified 2006).

18 Roder, W. 2001. Slash-and-burn rice systems in the hills of northern Lao PDR: description, challenges and opportunities. International Rice Research Institute, Los Banos.

19 George, T., Magbana, R., Roder, W., Van Keer, K., Trébuil, G., and Reoma, V. 2001. Upland rice response to phosphorus fertilization in Asia. Agronomy Journal 93:13621370.

20 Fahrney, K. 1999. Research priorities for upland ricebased agroecosystems in northern Laos. Completion of Service Report. International Rice Research Institute, Los Banos.

21 Roder, W., Keoboulapha, B., Phengchanh, S., Prot, J.C., and Matias, D. 1998. Effect of residue management and fallow length on weeds and rice yield. Weed Research 38:167-174.

22 Roder, W., Maniphone, S., and Keoboulapha, B. 1998. Pigeonpea for fallow improvement in slash-and-burn systems in the hills of Laos. Agroforestry Systems 39:45-57.

23 Roder, W., Maniphone, S., Keoboulapha, B., and Fahrney, K. 2006. Fallow improvement with Chromolaena odorata in upland rice systems of northern Laos. In M. Cairns (ed.). Voices from the Forest: Integrating Indigenous Knowledge into Sustainable Farming. RFF Press, Washington, DC. Chapter 14. p. 146-157.

24 FAO. 2004. Report of National Workshop on outcomes and impacts of the LAO-FAO TCP/LAO/2901 (A). Promotion of Organic Fertilizers at Plant Protection Center, Salakham. FAO, Field Document No. 9, Vientiane. 
25 IFOAM. 2005. The IFOAM norms for organic production and processing. IFOAM, Bonn.

26 Goubeaux. 1930. Rapport agricole du Laos pour l'année 1929. Inspection générale de l'agriculture de l'élevage et des forêts, Hanoi, Vietnam.

27 Roder, W., Phengchanh, S., Maniphone, S., Songnhikongsuathor, K., and Keoboulapha, B. 1995. Weed management strategies aimed at reducing labor for upland rice production. In: Fragile Lives in Fragile Ecosystems. Proceedings of the
International Rice Research Conference, February 13-17, 1995. International Rice Research Institute, Los Banos. p. 395-405.

28 Roder, W. and Maniphone, S. 1998. Shrubby legumes for fallow improvement in northern Laos: establishment, fallow biomass, weeds, rice yield, and soil properties. Agroforestry Systems 39:291-303.

29 Roder, W. and Maniphone, S. 1995. Forage legume establishment in rice slash-and-burn systems. Tropical Grasslands 29: $81-87$. 